\title{
Commercial Security Practices
}

\author{
Leander, Anna
}

Document Version

Final published version

Publication date:

2009

License

CC BY-NC-ND

Citation for published version (APA):

Leander, A. (2009). Commercial Security Practices. Department of Intercultural Communication and Management, Copenhagen Business School.

Link to publication in CBS Research Portal

\section{General rights}

Copyright and moral rights for the publications made accessible in the public portal are retained by the authors and/or other copyright owners and it is a condition of accessing publications that users recognise and abide by the legal requirements associated with these rights.

\section{Take down policy}

If you believe that this document breaches copyright please contact us (research.lib@cbs.dk) providing details, and we will remove access to the work immediately and investigate your claim. 


\title{
WORKING PAPER
}

\author{
2009 - nr. 5 \\ Monday, 30 November 2009
}

Commercial Security Practices

by Anna Leander

Professor (mso)

Department of Intercultural Communication and Management

Porcelænshaven 18 A, DK-2000 Frederiksberg

Copenhagen Business School 


\begin{abstract}
This entry gives an overview of the debate about private security. It can not pretend to cover everything in equal detail. It is geared to highlight the parts of the discussion about commercial security practices that are of most immediate interest to New Security Studies. Very succinctly put, the entry shows the pertinence of the emerging research agenda where commercial security practices are part of a broader analysis of evolving insecurities, of (in)security spaces and of everyday practices, insisting on the scope for further developments with regard to these issues (section 2). The entry also suggests that the although the more conventional literature on the subject-mostly framed in terms of privatization-has made valuable contributions to the debates about commercial security, it has limited analytical clout for analyzing the politics of commercial security. Worse it sometimes obscures it (section 1). It is therefore not surprising that commercialization is currently tending to replace privatization as the vantage point from which analysis is taking place.
\end{abstract}




\section{Commercial Security Practices}

By Anna Leander (ale.ikl@cbs.dk)

\section{Working Paper:}

Forthcoming in The Handbook of New Security Studies

edited by J. Peter Burgess (London: Routledge).

\section{Contents}

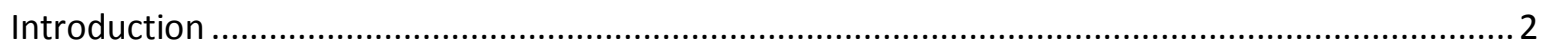

1. From Privatization of Security to Commercial Security Practices............................................ 2

a. Security privatization as a practical challenge ....................................................................

b. Security privatization and the transformation of states.................................................... 4

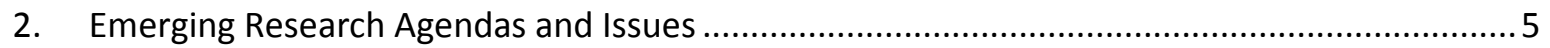

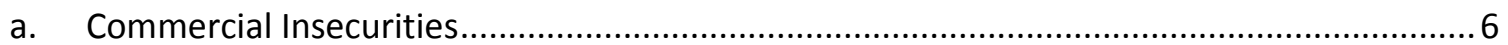

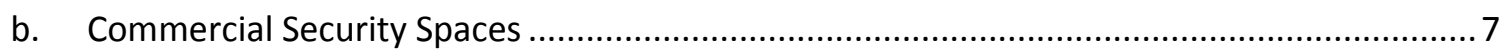

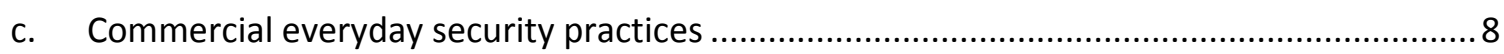

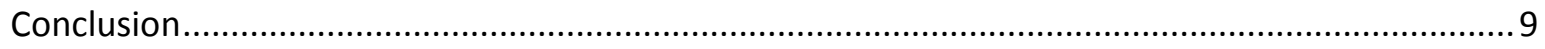

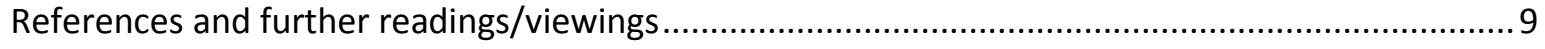




\section{Introduction}

The significance of commercial security practices is no longer news. The death of 17 civilians shot by Blackwater employees in Nisour Square Baghdad in September 2007, the diffusion of the Aegis "trophy" video showing firm employees shooting at random while "driving in Iraq" in 2004, the involvement of TITAN and CACI employees in the abuse of Abu Ghraib inmates in 2003/4, or the role of Executive Outcomes in the Sierra Leonean civil war 1995-6 are only some of the many spectacular events that have drawn attention to the growing role of commercial security practices in international security. Security commercialization has changed from being a rather obscure issue to being a highly publicized political bone of contention. Policy makers, NGOs, journalists, lawyers and academics strive to impose an understanding of commercial security, its problems and their possible solution. The result is an explosion in publications, including filmed documentaries and other media reports, about security commercialization. Voices from all political and academic horizons are striving to draw attention to the issues and questions they find most significant and pressing with regard to the development of security

This entry gives an overview of the resulting cacophony. It can not pretend to cover everything in equal detail. It is geared to highlight the parts of the discussion about commercial security practices that are of most immediate interest to New Security Studies. Very succinctly put, the entry shows the pertinence of the emerging research agenda where commercial security practices are part of a broader analysis of evolving insecurities, of (in)security spaces and of everyday practices, insisting on the scope for further developments with regard to these issues (section 2). The entry also suggests that the although the more conventional literature on the subject-mostly framed in terms of privatizationhas made valuable contributions to the debates about commercial security, it has limited analytical clout for analyzing the politics of commercial security. Worse it sometimes obscures it (section 1). It is therefore not surprising that commercialization is currently tending to replace privatization as the vantage point from which analysis is taking place.

\section{From Privatization of Security to Commercial Security Practices}

The end of the cold war ushered in a profound change in the role of commercial security. Although private firms had important roles in arms production, logistics and even security provision also earlier, the magnitude of their presence increased exponentially. The peace dividend the reduction of military expenditure was expected to generate with the end of the cold war was channeled into the emerging market and kept it growing. In the process, the roles firms took on changed. Military training and consultancy, intelligence and planning were outsourced to degrees unthinkable during the cold war. But perhaps the most significant, change is that military firms were increasingly expected to behave as private sector firms, to compete in markets and make a profit (Kaldor et al. 1998, Markusen et al. 2003, Susman and O'Keefe 1998). This entailed a detachment from the state. Although this process is still incomplete and patchy - many firms remain closely tied to states and states weigh heavily on the markets - a global market for force has developed. In this market private business is private, acting for commercial reasons and not merely as extensions of their home states. The processes of "discovering" this market has been a gradual one, driven by a practical need to respond to the challenges of the market and an academic concern with its implications for the future of the state.

\section{a. Security privatization as a practical challenge}

Not only NGOs, academics and lawyers but also the policy-makers, administrators and security professionals have come discuss security privatization largely in response to practical challenges it poses. Three recurring and challenges dominating the debate are introduced here. 
A first practical challenge has been (remains) to get basic knowledge about the private security sector, to get a grasp of how big it is, what activities firms engage in, where and why. There has been a striking shortage of adequate information about the private military/security sector. Estimates, more akin to wild guesses, have circulated and been used to convey the rapid expansion and growth of the market. The private military sector reportedly doubled in size between 1990 and 1999 (\$55 to \$100 bn.) and is expected to double again by 2010 (reaching \$200 bn.). The increased ratio of contractors to US soldiers is another figure often brandished to drive home the point. It said to have been 1-60 in the 1991 Gulf war and to have become 1,3-1 in Iraq 2007. The guess work in these figures is considerable: The overall industry figures are produced without a clear understanding of the boundaries of private military/security and based on figures that neither firms nor states are interested in providing. Figures about soldier contractor ratios are just as uncertain. Most states do not publish information on contractors (most do not collect that information) and even when they do (as the US has started to) these figures do not include the contractors that are hired (sub-contracted) by contractors or hired by e.g. firms, international organizations, NGOs or journalists. Considering the debilitating effects of this lack of clarity about the nature, scope and activities of the private military/security market for any practical engagement with the market, it is far from surprising that much energy has gone into raising awareness about privatization and simply documenting commercial military/security or an aspect thereof. The numerous reports and books striving to reveal private security, to show its origins, spell out the range of its activities and create awareness of its implications are attempts filling this lacuna (Rasor and Bauman 2007, Scahill 2007, Singer 2003, Shorrock 2007, Young Pelton 2006).

A second practical challenge that has been central in the discussion of security privatization is the role of managing and controlling economic efficiency. The promise of increased effectiveness, of diminished red tape and possibly even of more proficient and professional soldiering played no small part in motivating the turn to commercial military/security; checking if this promise is realized has been correspondingly important. This is true in the journalistic world but also inside public institutions and in academia. Markusen (2003) criticizes the criteria and information used compare public and private military service providers. She shows that the while the private sector enjoys a strongly positive bias which makes it possible to turn failure into exception and to use anecdotal examples as evidence of success, public service providers suffer an inverse fate. But more than this, their costs are systematically ignored as is the role played by social and political rules established for good reasons in creating the "lack of flexibility" of they stand accused. Similarly, exploring and deploring the deficiencies in the management of contracts and the perverse consequences of this in terms of costs incurred to the public and damage done to the armed forces is central in the work of Rasor and Bauman. With regard to the US, the possibly most informative source in this regard is the discussion inside state institution and particularly the reports of the GAO (government accountability office), the Congressional hearings on contracting, and the reports issued by DoD. Regrettably no other country publishes comparable information, which does not (sic) mean that they do not outsource or that there are no problems.

Finally, the practical challenge of legal accountability has taken on a pivotal role in the debate. There has been a "mad scramble" to bring private companies to justice (Kierpaul 2008). First, there is a prolific production of scholarly articles debating how private companies may be held responsible for their impact in war zones - in particular for their treatment of civilians - under international human rights law (Coleman 2004, Hallo de Wolf 2007) or under alternative regulations, including military regulations, self-regulation or the development of international standards (Chesterman and Lehnardt eds 2007). In practice companies still benefit from a "culture of impunity" (War on Want, 2007, Leander WP). The ICRC and Swiss government concerted efforts to alter this by pushing through the adoption of the Montreux Document (2008)—encouraging states to shoulder 
their International Human Rights Law obligations_-signals a growing political willingness to tackle this problem. Second, the accountability of the firms towards their employees is receiving attention. Blackwater's responsibility towards its employees that were lynched and burnt in Fallujah as well as the court case against the company in relation to a helicopter crash killing three of its employees in Afghanistan epitomize a trend which is also being extended to cover the fate of employees from "third countries” such as Namibia, Tanazania, Peru, Columbia or the Phillipines (UN Working group reports). Third and finally, the relations between the military and the market raise a range of accountability issues. The extent to which market actors are accountable to the military-for example the extent to which they have to deliver services and obey orders independently of the conditions-is unsettled. Contractors are ruled by contracts usually allowing them to stay out of "harm's way" but they are also an integral part of military operations (Zamparelli 1999). Inversely, whether or not the military can be held accountable for the fate of contractors, and has an obligation to devote resources to protect them, remains unsettled.

Reactions to the practical challenges of security privatization are bound to remain essential in reflections about security privatization. So far they constitute the bulk of the literature on the topic and provide invaluable insights. Without interest in tackling practical challenges we would hardly know anything about military/security privatization.

\section{b. Security privatization and the transformation of states}

As awareness of military/security privatization has increased the discussion has slowly made its way into academic political science and international relations (IR). The time is past when a senior Harvard scholar could answer a PhD student who wanted to write on the topic that it was suited for fiction and fantasy but hardly for academic work. The statism in IR and political science combined with the focus on privatization is that the resulting scholarly production has concentrated on the question of how privatization transforms states. Three key themes from this scholarship are introduced below.

The first and overarching theme is the general question of how military/security privatization affects the "state monopoly on the legitimate use of force" (the SMLF). This question has become central because the SMLF is integral to the conceptualization of the modern state in political science/IR. In the sociological tradition of Weber, Elias or Tilly it defines it. Discussing transformations of the SMLF therefore amounts to nothing less than to discussing changes in what the state is and what can be expected from it. Singer's pioneering work, covered or hinted at many of the key ensuing issues that arise in this consequence and that have later been brought up and discussed in detail elsewhere (2003 part III). Amongst other things it brings up the question of the implications of privatization for the global Balance of Power, for the balance between Civil and Military institutions at home and for the morality/ethics of warfare. Singer's conclusion is fairly straightforward: the SMLF is transforming profoundly but not disappearing. This conclusion is echoed by most scholars who have subsequently worked on the SMLF (Avant 2005, Krahmann 2007, Leander 2006 and WP). Scholars focusing on long term transformation emphasize that the transformations are overstates and instead underline the stability of norms (Lynch and Walsh 2000, Percy 2007) and/or the historicity of the market (Milliard 2003). However, few deny that taking the modern state and international state system as a reference point (i.e. not going back further than the 1850s) the surge in commercial activity since the end of the cold war is a transformation.

This acknowledgement of transformation however merely raises a whole new range of issues about the extent and implications of the transformation of the SMLF. Two issues in particular have galvanized scholars. The first is the extent to which the transformation of the SMLF also entails a substantive change in politics inside states. It has for example been asked whether or not privatization alters the way that policy agendas are set (Leander 2005b), the way security policy is carried out and 
hence the provision of public security (Leander 2005a, Cockayne 2006, Spearin 2008) or the way democratic processes function (Avant 2007 and Verkuil 2007). The second issue where concern is raised is whether or not privatization is altering the politics among states in the international system in significant ways. Does privatization make states more militaristic and war prone ? For some it is clear that the market is merely a too in the hands of the state (Shearer in Cambridge Review 1998) for others it is the sine qua-non of contemporary militarism (Tiefer 2007). Or does privatization reshuffles hierarchies among states. Again answers vary. While some scholars have suggested that the market can be used by weak states to strengthen and develop their military forces (Gumdeze 2007 at ISS), critical voices have suggested that private markets open the way for new forms of decentralized imperialism weakening the weakest states (Francis 2005, Leander 2009, Musah 2002). The questions are clearly essential and the literature on security privatization has made an important contribution to public debate by raising them.

However at the same time, the literature on privatization has serious shortcomings that explain the importance of replacing the privatization terminology with a commercialization (or commodification) one. The most serious of these short comings is that the privatization terminology tends to underrate — not to say obscure - key political processes. Logically, in a discussion framed in terms of privatization there is a tendency to look for "privatization"-i.e. shifts from a public to a private sphere. But this distracts attention from the most pressing political questions raised by privatization/commercialization. It is increasingly clear that the possibly most significant changes triggered by privatization/commercialization have little to do with shifts from the public to the private and much more to do with ways in which commercialization shapes how security is understood, how security spaces are delimited and how security is practiced in public and private institutions. Commercialization matters mainly because of the shifts in substantive politics that span the publicprivate realms (Leander 2003, Krahmann 2007, Abrahamsen and Williams 2007). There is consequently an emerging research agenda where the focus of the discussion shifts as the discussion is framed in terms of commercialization and integrated with the broader "new" or "critical" security agenda.

\section{Emerging Research Agendas and Issues}

Instead of pitting the development of commercial security against the state-as the privatization terminology does - there is a growing strand of research conceptualizing it within a broader framework of societal change. From this perspective the commercialization of security should be read as part of the deepening of liberal or neo-liberal forms of government. Governance increasingly takes decentralized forms working through quasi-markets, responsibilization and empowerment. States rely on firms as partners in government. This is true of security governance where (at least in the EU) the public wish to set up such partnerships surpasses the willingness of private military/security actors to engage in them (Dorn and Levi 2007). More generally this is driven by the centrality of risk. Individuals and companies are expected to insure against risk, for example by acquiring protection in the open market. From this perspective it is inadequate to pit military markets against states and weight their significance by looking at their impact on the SMLF. To capture salience of these developments requires displacing attention from privatization and fixing it on the consequences of governing security through markets and quasi-markets. The literature on military/security privatization is taking this direction as signaled by the focus on commercial practices and commodification. Simultaneously, scholars working on new and critical security approaches are beginning to integrate commercial practices in their work. Three themes emerging from the resulting research are introduced below: the commercial production of new insecurities, the commercial refashioning of security spaces and the commercial everyday security practices. 


\section{a. Commercial Insecurities}

One emerging theme is the study of how commercialization is (re-)shaping the way (in)security is understood. This reflection is feeding into analysis of how (in)security is constructed, not necessarily through speech acts establishing it as an existential threat warranting emergency measures (Copenhagen School style securitization) but also and more generally through practices, including routine practices, that frame specific issues as security issues and hence justify possibly equally routine like measures (Paris School style securitization). Military/security commercialization might be expected to have implications for both types of construction of insecurities. It is hence being integrated in the study of these.

First, commercialization could be expected to alter both who is engaged in (speech act type) securitization and how. Private commercial military/security experts have established themselves as interlocutors in debates about insecurity and protection. As research on intelligence transformation testifies, private companies have established themselves as key sources not only of information but of analysis and agendas (Shorrock 2007). This raises the question about the extent to which commercial actors and markets have to be integrated in the study of securitization discourses. Are there new authorized speakers? Is there a need to move from the discourses of foreign ministers and high politics to one that includes markets? More than this, does the heavy presence of commercial actors change the way that securitization discourses work and hence demand revisions of the literature on the processes of securitization? Does an understanding of the Austinian "felicity conditions" of securitizing speech acts increasingly pass through an understanding of the commercial security sector? Does commercialization tend to tilt the balance away from an emphasis on national interests and politics towards arguments about cost-effectiveness and feasibility? Research on these issues is emerging (Leander 2005b) but much work is needed to elaborate, contextualize and refine understandings and arguments.

Second, commercialization might be expected to alter routine practice type securitizations. Not primarily because private security professionals are fundamentally more sanguine more conspiring or less ethical than public ones. Security professionals more often than not share the same the training and professional background and the call on who is the most ethical and least conspiring is still open (Lynch and Walsh 2000 vs. Singer 2007). However, as the broader literature on neoliberal governance forms has persuasively shown for other areas, the shift in form and rationale of government also entails often unarticulated reshuffling of political priorities and aims as actors have to reshuffle their practices to suit new rules and requirements. How exactly this plays out in the security sphere is unchartered terrain. It has been argued that commercialization increases the pressure on public and private security professionals alike (as well as on all those in the enmeshed sphere where the two merge) to "sell" their own message about insecurity and appropriate responses to an ever expanded number of potential clients/investors. As commercial indicators were introduced to govern armed forces and military/security in the wake of the cold war; both logically engaged intensified their selling striving to conquer new "markets" for themselves. The consequence was a militarization of new geographic areas of the world (and especially of the NICs and China). It was also a militarization of new areas of public life as military technologies, techniques and knowledge were extended and adapted to new commercial employments. These processes have been traced for example in work on policing and justice (Haggarty 1999, Haggarty and Ericsson eds 2006). However, this work is more of a pointer in the direction of a vast potential area of research which is just beginning to emerge.

Most questions regarding the way commercial military/security alters (expands?) routine based securitization across contexts and the reshuffling of political priorities and aims resulting from this, still remain unanswered. The same can of course be said about the theme of the links between 
securitization and speech act type securitizations. In fact, one can see the two remaining emerging research themes partly as attempts to grapple with different aspects these issues.

\section{b. Commercial Security Spaces}

The second emerging research theme where commercialization has entered directly into contact with new and critical security studies is in relation to its centrality for the re-configuration of security spaces. Commercialization has been pulled into thinking about the processes through which boundaries and borders are produced and managed, i.e. about the way identities are stabilized and subjectivities produced. Commercialization plays a role in defining why and how some people become threatening outsiders while others are embraced as protection worthy insiders.

Along these lines, the commercialization of security has been tied to the transformation of the practices upholding, managing and producing territorial borders. It has been suggested that commercialization is key in altering everything about territorial borders. At the most banal level it has altered who is engaged in ensuring that the border is respected. Private companies are hired into airports, border-crossings and checkpoints to take over context defined parts of the border controls. This has altered how border controls are carried out and managed as new technologies both to control travellers-profiling, bio-metric controls, data-mining and blacklists-and to control the controllers have altered who is likely to experience difficulties crossing a border and who is not. But more than this producing the border has become largely separate from the state. Transport companies and in particular air and shipping companies shipping are held responsible through a range of (contextually varying) regulations for securing that the migrants they carry are "legal” (Giraudon 2001, Salter 2008). As these studies, show this change in who implements the border has entailed a change also in the practical exercise of authority; the decision to carry or not a person (and hence to grant access or refuse it) rests with a commercial actor. By the same token it has entailed a de-politicization of the criteria; actual decision making is drifting outside the public sphere. Finally, it has changed the geographical location of the border as control is increasingly off-shored and de-territorialized (Gammel-Toft Hansen 2009).

The effects of commercialization on the production and upholding of the borders between social groups may be just as far reaching. An explicit and key aspect of liberal thinking is that markets work effectively in part because they create incentive structures rewarding individuals who are efficient. The positive valuation of inequality implied, has been amply discussed across politics in a variety of areas. With regard to the commercialization of security it has been showed to alter the practices of security professionals and to create justificatory discourses that taken together have profound implications for who can claim and expect to get what kind of security. Studies of the evolving urban security spaces where gated communities co-exist with no-go zones have suggested a deepening gap between insiders and outsiders rigidifies in time as the boundaries become increasingly difficult to cross (Bislev 2004). Analogous points have been made with regard the effects of commercializing the management of crime and punishment more generally (Harcourt 2005, Zedner 2006). The consequence is a redrawing but also a hardening of the boundaries between individuals cast as social insiders and those cast as social outsiders. This is a process with ramifications far beyond the national community as it directly feeds into the view of minorities, immigrants and migration in general. It is part and parcel of producing the "ban-opticon" (a governance dispositif of bans, restrictions and prohibitions) Bigo suggests is increasingly central for governance in the contemporary world (2008).

These explorations of linking commercial security practices refashion security spaces are far from complete. There is ample scope for further work refining and differentiating our understanding of the processes at work in different contexts. More than this, thinking about strategies that might increase critical awareness of the role of commercialization in boundary drawing processes is still 
sparse. Yet for practical reasons, including for example for protecting the rights of travellers, or of football hooligans, it is vital to update the understanding of the location and underlying assumptions that govern the practices defining these spheres. Perhaps even more important, increasing awareness of the role of commercial practices in shaping boundary drawing processes may be crucial for anyone striving to engage in the politics questioning these processes; that is in politics regarding the inside/outside in the widest sense.

\section{c. Commercial everyday security practices}

Finally, a third theme of research emerging from the current research on commercial security practices concerns is the link between these practices and everyday (security) practices in different groups including security professionals, public administrators but also the private individual and citizen.

The consequence of commercialization on the institutional culture of security professionals (police and armed forces) is for example an issue of major importance that is beginning to receive attention among military sociologists and beyond. Some have taken the view that commercialization and the involvement of public security professionals in the market is most likely to lead to the spread of the prevailing public values and culture in the market as the actors there comply with a "logic of appropriateness" (Avant 2005). However, there are good reasons to think that the processes are less straight forward. The market may well be developing its own professional security culture where customer service and contract fulfilment make choices by public and private security officials differ substantially. For example, the Blackwater employees killing 17 civilians in Nisour Square Iraq (sept. 2007) clearly attached less importance to "winning hearts and minds" and more to protecting their client than the American soldiers subsequently criticizing their behaviour. Even further, it has further been argued that market culture (rather than public culture) might become the "logic of appropriateness" fashioning the attitudes and behaviour of security professionals (Leander 2006, Leander WP). The consequence of this for issues as diverse as gender roles in the armed forces, the professional military ethos or the inscription of these changes in a broader social and political context remains all but unexplored. This discussion about changes in the everyday practices of security professionals and its consequences is no more than insipient. There is a blatant need for a better and contextualized understanding of these processes as they are bound to vary as much as does the culture of security professionals and commercialization.

This comment also pertains to the emerging research where the commercialization of security practices is brought into the study of everyday security practices in the broad public. First, commercialization has gone in pair with the spread of images "branding" issues as security issues and "marketing” especially designed solutions to security problems. The consequence is a diffuse reshaping of visual culture. The development of video games, integrating pictures from real battles, and used both for simulation in the armed forces and sold on the open market (Lenoir 2000, Der Derian 2001) might be expected to contribute significantly to the "militarization of visual culture" explored by e.g. Campbell and Shapiro (2007). Similarly, commercialization might be expected to be driving the designing of security into everyday practices (Weber and Lacy in this handbook). However, far more work needs to be done on these links and their significance. In addition, commercialization has engendered a wide range of new governance mechanisms - such as surveillance equipment, reporting schemes and bench-markings and risk related concepts— that are promoted as providing protection against various risks. These mechanisms profoundly refocusa everyday practices on security in areas as diverse as financial markets and local government (Power 2007, de Goode 2008, Salskov-Iversen 2009). Again, contextually anchored analysis of these processes is key to an assessment of the increasing role of security in everyday practices beyond the security sphere proper. 


\section{Conclusion}

The privatization or commercialization (as this article has suggested we better say) of security has been the subject of considerable scholarly, journalistic and media work. This entry has sketched out some of the key debates and arguments. It has insisted first on the centrality of the practical challenges of understanding the market and sorting out accountability issues and, second, on the transformation of statehood. These two issues are usually framed in terms of privatization. However, the limits of this framing for understanding substantive changes in politics (as opposed to statehood) has led to a trend focussing on understanding the commercialization and commodification of security. This research agenda meets the new security research agenda as it feeds into discussions about the formation of (in)securities, the boundaries of (in)security spaces and about everyday (in)security practices. As any sketching or "overview" this one is simplifying. However, the intention with this simplification has emphatically not been to close down inquiry by suggesting that the issues have been exhaustively or satisfactorily covered. On the contrary, a very explicit effort has been made to underline the opposite, namely that there is plenty of work to be done and that most questions are still either unanswered or profoundly contested. By way of conclusion, it is appropriate to follow this up with an insistence that there are certainly innumerable important issues and questions that have not been given any space at all in this entry. If the entry has triggered awareness of such issues, it has done well. The references and links below are intended to provide entry points for anyone wishing to go further.

\section{References and links}

\section{Useful weblinks:}

The British Association of Private Security Companies (UK Based industry organization) http://www.bapsc.org.uk/

The Geneva Centre for the Democratic Control of Armed Forces programme on the Privatization of Security: http://www.privatesecurityregulation.net/introduction

The Institute for Security Studies (Pretoria ZA) privatization project

http://www.issafrica.org/index.php?link_id=30\&link_type=12\&tmpl_id=2

The International Consortium of Investigative Journalists project on the business of war http://projects.publicintegrity.org/bow/

The International Peace institute database over researchers on international private security http://www.ipinst.org/our-work/coping-with-crisis/grips/

The International Peace Operations Association (US based industry organization)

http://ipoaworld.org/eng/

Private Military Org. Provides useful company links and links to literature http://www.privatemilitary.org

All major firms run their own very instructive websites.

\section{Reports/Official Documents}

British American Security Information Council: Isenberg, David. (2004) A Fistful of Contractors: The Case for a Pragmatic Assessment of Private Military Companies in Iraq (available at http://www.basicint.org/pubs/Research/2004PMC.htm ).

Brookings: Singer, Peter W. (2007) 'Can't Win with 'Em, Can't Go to War without 'Em: Private Military Contractors and Counterinsurgency'. Foreign Policy at Brookings. Policy Papers(4). (available at: http://www3.brookings.edu/papers/2007/0927militarycontractors.aspx ) 
GAO. (2008) 'Military Operations: Implementation of Existing Guidance and Other Actions Needed to Improve DOD's Oversight and Management of Contractors in Future Operations'. Washington D.C.: GAO (available at http://www.gao.gov/new.items/d08436t.pdf ). GAO produces a great number of relevant reports on US commercialization. Appendix 1 contains a list of reports related to this one.

The Montreux Document: Promoted by the ICRC and now officially adopted by key contracting states including the US and the UK (available at www.icrc.org/web/eng/siteeng0.nsf/htmlall/montreux-document-170908)

The UN working group on the use of mercenaries... (see particularly the annual reports!) http://www2.ohchr.org/english/issues/mercenaries/wgstandards.htm

War on Want: campaign against corporate mercenaries with a very useful report detailing the culture of impunity http://www.waronwant.org/Corporate+Mercenaries+13275.twl

\section{Monographs by journalists/insiders}

Barlow, Eeben. (2008) Executive Outcomes: Against All Odds: Galago Publishing.

London, J. Phillipe and the CACI Team. (2008) Our Good Name: A Company's Fight to Defend its Honour and Get the Truth told About Abu Ghraib. Washington D.C.: Regenery Publishing.

Pelton, Robert Young. (2006) Licensed to Kill: Hired Guns in the War on Terror. New York: Crown Publishers.

Rasor, Dina and Bauman, Robert. (2007) Betraying Our Troops: The Destructive Results of Privatizing War. New York: Palgrave.

Scahill, Jeremy. (2007) Blackwater: The Rise of the World's Most Powerful Mercenary Army. Washington: Nation Books.

Shepherd, Bob. (2008) The Circuit: An Ex-SAS Soldier's True Account of One of the Most Powerful and Secretive Industries Spawned by the War on Terror London: Macmillan.

Shorrok, Tim. (2008) Spies for Hire: The Secret World of Intelligence Outsourcing. New York: Simon \& Schuster.

Spicer, Tim Lt Col. (1999) An Unorthdox Soldier: Peace and War and the Sandline Affair. Edinbrurgh: Mainstream.

\section{Academic Monographs and Edited Volumes}

Abrahamsen, Rita and Williams, Michael C. (2007) 'Special Issue: The Privatization and Globalisation of Security in Africa'. International Relations, 21(2).

Avant, Deborah. (2005) The Market for Force: The Consequences of Privatizing Security. Cambridge: Cambridge University Press.

Cambridge Review of International Affairs. (1998) 'Special Issue on Private Military Companies'. Cambridge Review of International Affairs, XIII(1).

Chesterman, Simon and Lehnardt, Chia eds. (2007) From Mercenaries to Markets: The Rise and Regulation of Private Military Companies. Oxford: Oxford University Press.

Der Derian, James. (2001) Virtuous War: Mapping the Military-Industrial-Media-Entertainment Network. Boulder CO.: Westview Press.

Kaldor, Mary, Albrecht, Ulrich and Schméder, Geneviève eds. (1998) Restructuring the Global Military Sector. The End of Military Fordism. London: Pinter.

Giraudon, Virginie. (2001) Controlling a New Migration World. London: Routledge.

Harcourt, Bernard H. (2005) Language of the Gun: Youth, Crime, and Public Policy. Chicago: The University of Chicago Press.

Leander, Anna. (2006) Eroding State Authority? Private Military Companies and the Legitimate Use of Force. Rome: Centro Militare di Studi Strategici.

Markusen, Ann, DiGiovanna, Sean and Leary, Michael C. eds. (2003) From Defense to Development? International Perspectives on Realizing the Peace Dividend. London and New York: Routledge.

Musah, Abdel-Fatau and Fayemi, Kayode J. eds. (2000) Mercenaries: An African Security Dilemma. London: Pluto Press. 
Power, Michael. (2007) Organized Uncertainty: Designing a World of Risk Management. Oxford: Oxford University Press.

Singer, Peter W. (2003) Corporate Warriors. The Rise of the Privatized Military Industry. Ithaca and London: Cornell University Press.

Susman, Gerald and O'Keefe, Sean eds. (1998) The defense industry in the post-Cold War era : corporate strategies and public policy perspectives: Pergamon.

Verkuil, Paul. (2007) Outsourcing Sovereignty: Why Privatization of Government Functions Threatens Democracy and What We Can Do about It: Why Privatization of Government Functions ... Democracy and What We Can Do About It. Cambridge: Cambridge University Press.

\section{Academic Articles}

Abrahamsen, Rita and Williams, Michael C. (2007) 'Selling Security: Assessing the Impact of Military Privatization (book review essay)'. Review of International Political Economy, 15(1):131-46.

Bigo, Didier. (2008) 'Globalized (In)security: The Field and the Ban-opticon', In Terror, Insecurity and Liberty: Illiberal Practices of Liberal Regimes, eds. Bigo, Didier and Tsoukala, Anastassia. New York and London: Routledge.

Buur, Lars. (2006) 'Reordering society: Vigilantism and sovereign expressions in Port Elizabeth's townships'. Development and Change, 37(4):735-57.

Campbell, David and Shapiro, Michael J. (2007) 'Introduction to Special Issue on Securitization, Militarization and Visual Culture in the Worlds of Post 9/11'. Security Dialogue, 38(2):13137.

Cockayne, James. (2006) 'Commercial Security in the Humanitarian Space'. International Peace Academy.

Coleman, James R. (2004) 'Constraining Modern Mercenarism'. Hastings Law Journal, 55(June):1493-537.

De Goede, Marieke. (2008) 'Beyond Risk: Premeditation and the Post-9/11 Security Imagination'. Security Dialogue, 39(2-3):155-76.

de Wolf, Antenor Hallo. (2006) 'Modern Condottieri in Iraq: Privatizing War from the Perspective of International and Human Rights Law'. Indiana Journal of Global Legal Studies, 13:315-56.

Dorn, Nicholas and Levi, Michael. (2007) 'European Private Security, Corporate Investigation and Military Services: Collective Security, Market Regulation and Structuring the Public Sphere'. Policing \& Society, 17(3):213-38.

Dorn, Nicholas and Levi, Michael. (2007) 'Private-Public or Public-Private? Strategic Dialogue on Serious Crime and Terrorism in the EU'. Security Journal (August).

Francis, David J. (1999) 'Mercenary Intervention in Sierra Leone: Providing National Security or International Exploitation?' Third World Quarterly, 20(2):319-38.

Haggerty, Kevin D. and Ericson, Richard V. (1999) 'The Militarization of Policing in the Information Age'. Journal of Political and Military Sociology, 27 (winter):233-55.

Hallo de Wolf, Antenor. (2007) 'Modern Condottieri in Iraq: Privatizing War from the Perspective of International and Human Rights Law'. Indiana Journal of Global Legal Studies, 13(315).

Gammeltoft-Hansen, Thomas. (2009) 'The Refugee the Sovereign and the Sea: European Union Interdiction Policies', In Sovereignty Games: Instrumentalising State Sovereignty in Europe and Beyond, eds. Adler-Nissen, Rebbecca and Gammeltoft-Hansen, Thomas. London: Palgrave: 171-195.

Power, Michael. (2005) 'The invention of operational risk'. Review of International Political Economy, 12(4):577-99.

Kierpaul, Ian. (2008) 'The Rush to Bring Private Military Contractors to Justice: The Mad Scrambel of Congress, Lawyers, and Law Students after Abu Ghraib'. The University of Toledo Law Review, 39:407-35.

Krahmann, Elke. (2007) 'Security: Collective Good or Commodity? ' European Journal of International Relations, 14(3):379-405. 
Leander, Anna. (2003) 'The Commodification of Violence: Private Military Companies and African States', In The Making of the Africa-Nation: Pan-Africanism and the African Renaissance, ed. Muchie, Mammo. London: Adonis-Abbey: 264-80.

Leander, Anna. (2005) 'The Market for Force and Public Security: The Destabilizing Consequences of Private Military Companies'. Journal of Peace Research, 42(5):605-22.

Leander, Anna. (2005) 'The Power to Construct International Security: On the Significance of Private Military Companies'. Millennium Journal of International Studies, 33(3):803-26.

Leander, Anna. (2009) 'Securing Sovereignty by Governing Security through Markets', In Sovereignty Games: Instrumentalising State Sovereignty in Europe and Beyond, eds. Adler-Nissen, Rebbecca and Gammeltoft-Hansen, Thomas. London: Palgrave: 151-170.

Leander, Anna (WP) working papers on civil military relations, the impunity of contractors, international legal instruments of regulation and industry self images are available at www.cbs.dk/content/view/pub/38570.

Lynch, Tony and Walsh, A. J. (2000) 'The Good Mercenary'. Journal of Political Philosophy(8):13353.

Markusen, Ann R. (2003) 'The Case Against Privatizing National Security'. Governance: An International Journal of Policy, Administration, and Institutions, 16(4):471-501.

Milliard, Major Todd S. (2003) 'Overcoming Post-Colonial Myopia: A Call to Recognize and Regulate Private Military Companies'. Military Law Review, 1(8).

Percy, Sarah. (2007) 'Mercenaries: Strong Norm, Weak Law'. International Organization, 61(2):36797.

Salter, Mark. (2008) 'Imagining Numbers: Risk, Quantification, and Aviation Security'. Security Dialogue, 39(2-3):243-66.

Sapone, Montgomery. (1999) 'I have rifle with Scope, will travel: The Global Economy of Mercenary Violence'. California Western International Law Journal, 30(fall):1-43.

Singer, Peter W. (2007) 'Can't Win with 'Em, Can't Go to War without 'Em: Private Military Contractors and Counterinsurgency'. Foreign Policy at Brookings. Policy Papers(4).

Spearin, Christopher. (2008) 'Private, Armed and Humanitarian? States, NGOs, International Private Security Comapnies and Shifting Humanitarianism'. Security Dialogue, 39(4):363-82.

Tiefer, Charles. (2007) 'The Iraq Debacle: The Rise and Fall of Procurement-Aided Unilateralism as a Paradigm of Foreign War'. University of Pennsylvania Journal of International Economic Law, 29(Fall):1-56.

Zamparelli, Colonel Steven J. (1999) 'Competitive sourcing and privatization: Contractors on the battlefield'. Air Force Journal of Logistics, XXIII(3):1-17.

Zedner, Lucia. (2006) 'Liquid Security: managing the market for crime control'. Criminology and Criminal Justice, 6(3):267-88. 